\title{
A Racionalidade Vitalista de Canguilhem e Suas Contribuições para a Humanização das Práticas de Cuidado em Saúde
}

\author{
Moreira, Adriana Belmonte \\ Universidade Federal do Parana — adribelmonte@bol.com.br
}

Introdução: a relevância do estudo de Canguilhem hoje reside no fato de que, já nos anos 40, ele colocava em questão o princípio de desindividualização da doença e o reducionismo físicoquímico na compreensão dos fenômenos vitais, principais características do pensamento biomédico moderno. Ele notava que seguindo uma orientação materialista mecanicista e reducionista, a prática clínica ficou aprisionada num esquema de causa e efeito entre o gesto terapêutico e seu resultado, reduzindo a relação médico-doente a um automatismo de ordem meramente instrumental. Todavia, apesar de todos os esforços de cientifização, a medicina é uma arte que encontra na relação médico-doente os elementos para a compreensão do patológico, pois é somente a clínica que coloca o médico em contato com o indivíduo concreto, que vivencia a angústia suscitada pela doença. Assim, tendo por pressuposto uma concepção de vivente que não a maquinal e de normalidade e de patologia, que não a científicoexperimental, mas axiológico-experiencial, ele elabora uma racionalidade em saúde que ao se inscrever na antiga tradição médica vitalista procura resgatar o sentido primeiro da clínica, que é o voltar-se ao leito do doente, entendido como um indivíduo concreto, histórico e culturalmente contextualizado. Objetivos: Apresentar os fundamentos da racionalidade vitalista canguilhemiana e suas contribuições para as práticas de cuidado em saúde na atualidade. Métodos: Análise do conjunto das obras do autor. Resultados: o núcleo da crítica de Canguilhem à medicina é o fato dela ter deixado de ser uma arte da cura para se tornar uma ciência das doenças. Apresentando uma concepção de medicina que não ancorada numa ciência biológica do normal, mas em situações biológicas consideradas normais, ele opera uma subversão no pensamento biomédico moderno, na medida em que coloca o doente, como indivíduo concreto, e não a doença, como entidade nosológica abstrata, no centro das práticas de cuidado em saúde. com isso, ele mostra ser imprescindível a escuta clínica para a definição do normal e do patológico, mais do que os exames de imagem e laboratoriais, já que é a vida mesma em suas atribuições de valor que fala através do doente, mostrando os caminhos para a cura. Além disso, propõe a relativização dos procedimentos médicos, já que cada doente é um indivíduo singular, com história, modo de vida e capacidade de resistência orgânica próprios. Conclusão: Se consideramos o pensamento de Canguilhem atual é porque faz frente à desindividualização própria ao modelo biomédico moderno e às práticas dele derivadas, que se pautam em conceitos abstratos de doença e em procedimentos universais, padronizados e socioculturalmente descontextualizados, o que faz do doente um objeto e não um sujeito, e dos serviços de saúde lugares de tratamento no anonimato e não espaços de acolhimento do sofrimento e da angústia de alguém, problemas que as políticas de humanização dos serviços de saúde ainda procuram solucionar.

Moreira, Adriana Belmonte. A Racionalidade Vitalista de Canguilhem e Suas Contribuições para a Humanização das Práticas de Cuidado em Saúde.. In: Anais do Congresso Internacional de Humanidades \& Humanização em Saúde [= Blucher Medical Proceedings, num.2, vol.1]. São Paulo: Editora Blucher, 2014. ISSN 2357-7282 DOI 10.5151/medpro-cihhs-10264 